\title{
Sympathy and Severity
}

The Father-Son Relationship in Early Medieval China

Sympathie et sévérité. La relation père-fils dans la Chine médiévale

衆父一一對一個古代中國名詞后経的幾點看法

\section{Keith Knapp}

\section{OpenEdition \\ Journals}

\section{Electronic version}

URL: http://journals.openedition.org/extremeorient/234

DOI: 10.4000/extremeorient.234

ISSN: 2108-7105

Publisher

Presses universitaires de Vincennes

\section{Printed version}

Date of publication: 1 January 2012

Number of pages: 113-136

ISSN: 0754-5010

Electronic reference

Keith Knapp, "Sympathy and Severity », Extrême-Orient Extrême-Occident [Online], Hors-série | 2012, Online since 01 January 2015, connection on 19 April 2019. URL : http://journals.openedition.org/ extremeorient/234 ; DOI : 10.4000/extremeorient.234 


\title{
Sympathy and Severity: The Father-Son Relationship in Early Medieval China
}

\author{
Keith Knapp
}

In 626, immediately after Prince Li Shimin (Emperor Taizong of the Tang, r. 627-649) ambushed and killed his two brothers [one of whom was the crown prince] at the Xuanwu Gate, claiming that they were leading a revolt, his father the emperor summoned him. "He [Emperor Gaozu, r. 617-626] soothed him saying, 'In recent days we nearly experienced a misunderstanding akin to the throwing away of the shuttle.' 'Shimin kneeled and puckered his lips to suck on his father's teat; he cried and grieved for a long time." 2 Through this act, Shimin expressed his grief that he and his father had lost the closeness they shared early in his life. A Chinese historian, Yan Aimin, has attempted to explain this passage by positing the existence within pre-Tang China of a phenomenon known as ruweng "nursing father" that emphasizes a father's nurturing aspect. He supports this conjecture by noting the existence of a custom later seen among southern aborigines known as chanweng "birthing father," in which a man takes the place of his postpartum wife in feeding the baby and lying with it. And the fact that in early China sagely kings were often said to have large breasts, or more than two. These physiological abnormalities were taken as signs of benevolence. ${ }^{3}$

1. This is an allusion to the story of Zengzi's mother being told her son was a murderer. A man from another county who had the same name as Zengzi committed murder. While working at her loom, Zengzi's mother was informed twice that her son was a murderer. Knowing that her son could never do such a thing, she merely continued working unperturbed at her loom. However, when she was told a third time, her faith in her son began to waver; as a result, she threw her shuttle down and ran away.

2. Yang Jialuo 楊家駱, Xinjiao Zizhi tongjian zhu 新校資治通鑑注 (rpt; Taipei: Shijie shuju, 1987): v. 10, 191.6012.

3. See Yan Aimin 閻愛民, “Zizhi tongjian ‘Shimin gui er shun shangru' de jieshuo - jiantan zhongguo gudai 'ruweng' yisu” 《资治通鉴》世民趾而吮上乳的解説 - 兼談中國古 代乳翁遗俗, Zhongguoshi yanjiu 中國史研究, $\mathrm{n}^{\circ} 3$ (2004): 73-78. 
No matter what the origins of this gesture are, it signals a close emotional and physical tie between father and son.

But how can this be? Most of us assume that in pre-modern China the father-son relationship was always marked by formality and emotional distance. No less an authority than the philosopher Han Feizi (ca 280-233) underscored that this was indeed the case. He notes that even though a mother loves her son twice as much as his father does, she usually fails to properly raise him because she relies on love rather than fear, intimacy rather than formality. Fathers, on the other hand, raise their sons well because they maintain clear lines of authority and rely on discipline rather than tenderness. As he noted, "Therefore mothers treat their sons with generous love, but most sons are spoiled because love is over used. Fathers are sparing in their love and teach through beating, but their sons are largely good. That is because they use severity." ${ }^{4}$ In other words, mothers smother their sons with love, while fathers remain aloof from them and enforce discipline. But was the father-son relationship so devoid of sentimentality and intimacy? In recent years, scholars from Japan, Taiwan, and the United States have produced first rate scholarship that delineates the profound emotional, social, and symbolic importance of the mother-son tie in early China. ${ }^{5}$ However, these studies often say little about the father-son relationship.

The purpose of this paper is to take a fresh look at the father-son relationship, particularly during China's early medieval period (100-600). I will argue that, although their relationship was marked by formality and decorum, fathers and

4. D.C. Lau 劉殿爵, Chen Fong Ching 陳方正, and Ho Che Wah 何志華, eds, Han Feizi zhuzi suoyin 韓非子逐字索引 (Hong Kong: The Commercial Press, 2000): 138. For a slightly different translation, see W.K. Liao, The Complete Works of Han Fei-tzu (2v. London: Arthur Probsthain, 1959): v. 2, 242.

5. See Miranda Brown, "Sons and Mothers in Warring States and Han China, 453 BCE-220 CE," Nannü, $n^{\circ} 5$ (2) (2003): 137-169; Kamiya Noriko 神矢 法子, Haha no tame mofuku: Chugoku kodai shakai ni miru fuken-fuken, tsuma = haha no chii ko no gimu 母のための喪服: 中国古代社会に見る夫権一父権 ·妻＝母の地位 ·子の義務 (Tokyo: Nihon Tosho Kankokai, 1994); Lee, Jen-der, "Wet Nurses in Early Imperial China." Nannü no 2 (1) (2000): 1-39; Scott Pearce, "Nurses, Nurslings, and New Shapes of Power in the Mid-Wei Court," Asia Major: Third Series, Part I, 22 (2009): 287-309; Shimomi Takao下見 隆 雄, Jukyô shakai to bosei 儒教 社會 と 母 性 (Tokyo: Kenbun shuppan, 1994), and Kô to bôsei no mekanizumu 孝と母 性 のメカニズ ム (Tokyo: Kenbun shuppan, 1997), and Zheng Yaru 鄭雅如, Qinggan yu zhidu: WeiJin shidai de muzi guanxi 情感與制度: 魏晋時代的母子關系 (Taipei: Guoli Taiwan daxue wenshi congkan, 2001). The single exception to this has been Yanxia Zhao's Father and Son in Confucianism and Christianity: A Comparative Study of Xunzi and Paul (Portland, OR: Sussex Academic Press, 2007). 
sons by and large had deep feelings of love and tenderness for each other. I will support this contention through examining filial piety stories and their pictorial representations, which show filial sons going to extraordinary lengths to make their fathers happy and secure. Many of these tales were propagated through private works known as Xiaozi zhuan "Accounts of Filial Children" that were produced and circulated in China from the second through the seventh century. Although nearly all of these books are only known through fragments preserved in medieval Chinese encyclopedias, two have survived intact in Kyoto, Japan. The earlier of the two texts is known as the Yomei Archive Accounts of Filial Children, which due to its tales' close resemblance to the iconography of Northern Wei (386-535) filial piety images, the Japanese scholar Kuroda Akira believes that it dates to the late fifth century. ${ }^{6}$ The second text, the Funahashi Accounts of Filial Children, which is related to the Yōmei Archive version, dates to the late sixth or early seventh century. ${ }^{7}$ Based on the tales found in the Accounts of Filial Children, we will look at three father-son motifs: sons who dedicate themselves to respectfully caring for their fathers; sons who fulfill the reciprocal obligations they owe their fathers; and fathers who realize they have mistreated their sons. All three motifs suggest that early medieval Chinese expected that sons would feel grateful to their fathers for their upbringing and would want to reciprocate. At the same time, although fathers had to enforce rules and were often misled by their wives, they deeply cared about the welfare of their sons.

Since one could easily make the case that these tales are probably merely pious fiction and present the father-son relationship in the most idealized manner, why bother studying them? Would we not be better off looking at how fathers and sons actually behaved towards each other? Such skepticism is warranted, but unfortunately there is not an abundance of material related to father-son relations during the early medieval period. There are also a number of positive reasons why filial piety tales are a valuable source of information. First, these narratives became tremendously popular among the ruling elite, which mean the tales can tell us much about that group's sentiments. Second, even though these narratives are not representative of how most people actually behaved, they do tell us how members of the upper class hoped fathers and sons would act towards each other. Third, since artisans would have chosen to depict those tales that were the most recognizable and crowd-pleasing, the

6. Kuroda Akira 黑田彰, “Yōmeihon Kōshiden no seiritsu” 陽明本孝子伝の成立, Kyōtō gobun 京都語文, $\mathrm{n}^{\circ} 14$ (2007): 57-136.

7. Kuroda, Kôshiden no kenkyû 孝子傳の研究 (Kyoto: Sibunkaku shuppan, 2001): 129-186. 
images of filial piety tales on everyday goods, walls of official buildings, and funerary goods, are probably the narratives that were the most popular; the scenes that artisans chose to illustrate from those stories were probably also the ones that people found the most evocative. Finally, because the images could be understood by both literate and non-literate audiences, the number and social class of their viewers could be quite broad. Hence, these illustrations reveal conceptions of the father-son relationship that might have been prevalent across social classes.

Admittedly, there are a greater number of early medieval filial piety narratives that focus on the mother-son relationship than the father-son relationship. As I noted in Selfless Offspring, out of 82 tales that have the motif of reverent care, 52 , or $63 \%$, have the mother as the recipient. Fathers enjoy reverent care in only 21 stories, or $25 \%$ of the tales. ${ }^{8}$ Since in East Asia affection is often expressed in the bestowal of a favorite food, that sons had closer feelings for their mothers can also be seen in that the numerous tales that feature the motif of sons obtaining their mother's desired food or medicine; tellingly, stories about fathers nearly entirely lack this motif. Nevertheless, numbers do not tell the entire story. Just as important are the tales' illustrations. One of the goals of this essay is to demonstrate that, in terms of their presence in filial piety images, narratives that concern fathers are much more prominent than their numbers warrant.

\section{Sons nurturing fathers}

A common motif in early medieval filial piety tales is that of a son taking care of his father's material needs. As noted in my book Selfless Offspring, such tales celebrate the principle of gongyang "reverent caring," in which a child nurtures his parent in a way that elevates the elder's status and denigrates his own. ${ }^{9}$ Two of the most common ways of illustrating this theme was through the motifs of a filial child offering his parent delicacies, while he contented himself with rough fodder, and that of a filial child who works as a hired laborer, a despised condition, to procure delicacies for his parents. One of the most popular tales that demonstrates this theme is that of Dong Yong. Early medieval versions of this tale stress how he cared for his elderly father. Cao Zhi's (192-232) "Essay on the Numinous Fungi" tells us that,

8. See my Selfless Offspring: Filial Children and Social Order in Medieval China (Honolulu: University of Hawaii Press, 2005): 134-135.

9. Ibid. : 113-127. 


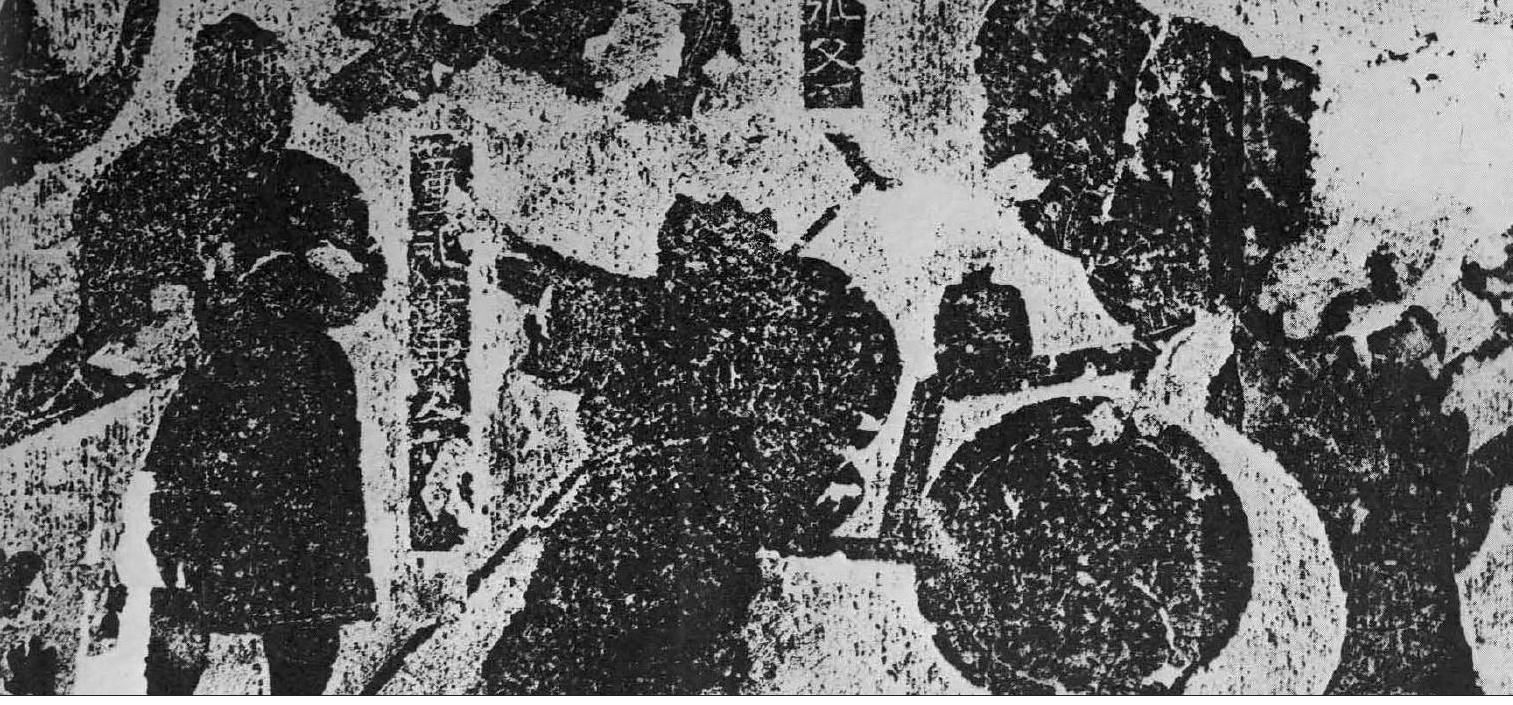

Figure \#1 : Dong Yong caring for his father in the field. Carving on pictorial stone. Wu Liang Shrine. Jiaxiang, Shandong Province, AD 151. Courtesy of Foreign Languages Press.

Dong Yong's family suffered from poverty: his old father had no riches to bequeath. He undertook to borrow to provide his father sustenance. He worked for hire to bring him dainties. Creditors filled his gate, but he didn't know how to repay them. The heavenly spirits were moved by his perfect virtue. A goddess took hold of a loom for him [and paid his debts]. ${ }^{10}$

This is probably the earliest written version of the Dong Yong story; interestingly, it combines both motifs: Dong Yong denigrates himself by working as a hired laborer to nurture his father. But he does so to not merely provide him with daily sustenance, but with delicacies that indicate his father's superior status. Note that reverent care is of such importance that Dong is willing to go heavily into debt to make sure that his father receives it.

Another early version of the story also emphasizes the thoughtful care that Dong Yong lavished on his father. This particular version is especially important because it was often illustrated. Here is how it starts:

A native of Chu Dong Yong was perfectly filial. While young, he lost his mother; as a result, he lived alone with his father. They were extremely poor and lived in great hardship. Dong Yong would hire out his labor for a wage to reverently care for his father. He would always use a deer cart to transport his father. [This way] his father could follow him and Dong Yong could place him under the cool shade of a tree. Each time he struck the ground with his hoe, he would look back at his father. He

10. Lau, Chen, and Ho, Cao Zhi ji zhuzi suoyin 曹植集逐字索引 (Hong Kong: Zhongwen daxue chubanshe, 2000): 106. 
would closely observe his father's countenance [to insure that he was pleased]. His reverent care was pure and rich. Day and night he was never lazy. ${ }^{11}$

This version makes Dong's love for his father plainly evident. To ensure that his father's every need is met, Dong brings him to the fields with him and constantly checks on him. To make sure he is comfortable, Dong parks the cart under the cool shade of a tree. Dong cannot be away from his father for a moment; his sole priority is guarantee that his father is well and comfortable. Images of this motif, which frequently appear in the tomb art of both the Eastern Han (25-220) and the Period of Disunion (220-589), show Dong's father comfortably seated in a small deer cart underneath a tree, while Dong Yong who is hoeing a field, looks back at his father to make sure he is content (see figure \#1). ${ }^{12}$ Through Dong Yong turning his head to look at his helpless father, the images of this scene vividly convey the tender concern that this son feels for his father. Without a doubt, early medieval Chinese would have felt touched upon seeing Dong's loving concern for his father. In contrast, by the Song (960-1279) and Yuan (1235-1367) periods, depictions of the Dong Yong tale for the most part focus on his relationship with the goddess that was sent to aid him. ${ }^{13}$

Another extraordinarily popular tale that emphasized a son's love for his father is that of Ding Lan. His parents died while he was young. Regretting that he never had a chance to reverently care for a parent, he carved from wood an image of father and served it as if it were alive. The inscription accompanying

11. Yōgaku no Kai 幼學の會, ed. Kōshiden chūkai 孝子伝注解 (Tokyo: Kyūko shoin, 2003): 39. Please note that this provides the texts, Japanese translations, and photographic reproductions of both the Yōmei Archive Accounts of Filial Children and the Funahashi Accounts of Filial Children.

12. For two Eastern Han depictions of Dong Yong looking after his father in the field, see Knapp, Selfless Offspring: 55. Many of the images of this motif can be found in Kōshiden chūkai: 410-414, and in Zou Qingquan 鄒清泉, Bei-Wei Xiaozi huaxiang yanjiu: Xiaojing yu Bei-Wei xiaozi huaxiang tuxiang shenfen de zhuanhuan 北魏孝子 畫像研究: 孝經與北魏孝子畫像图像身份的轉换 (Beijing: Wenhua yishu chubanshe, 2007): 64-65, 69, 70, 122-123.

13. Images from this period show the Heavenly Maiden leaving on a cloud while Dong Yong longingly gazes at her. For examples of these images, see Cui Yuanhe 崔元和, Pingyang Jinmu zhuandiao 平陽金墓磚雕 (Taiyuan: Shanxi renmin chubanshe, 1999): 239 and 254; Zhengzhou lishi wenhua congshu bianzuan weiyuanhui 鄭州歷史文化 叢書編纂委員會, Zhengzhou gumu bihua jingxuan 鄭州古墓壁畫精選 (Hong Kong: Xianggang guoji chubanshe, 1999): 134 and 141. Some images of this period from Gansu province still retain the motif of Dong Yong looking back at his father, but others have motif of him looking at the Heavenly Maiden as she leaves. See Chen Lüsheng 陳履生 \& Lu Zhihong 陸志宏, Gansu Song Yuan Huaxiangzhuan 肅的宋元畫像磚 (Beijing: Renmin meishu chubanshe, 1996): 5, 13, 26, 52, and 65. 
an illustration of this narrative at the Wu Liang Shrine (A.D. 151) furnishes our earliest version of this tale. It reads, "When Ding Lan's two parents died, he erected a piece of wood and made it into [an image of] his father. When a neighbor wanted to borrow something, [Ding] would only do so after he reported it [to his father]." ${ }^{14}$ Ding Lan was so distraught that he could not express his love for his departed parents by reverently caring for them that he created a wooden surrogate. Significantly, in Eastern Han depictions of the tale, even though both parents had died, he chose to create an image of his father. Cao Zhi's "Essay on the Numinous Fungi" (Lingzhi pian) furnishes more information:

Ding Lan lost his mother while young and was broken-hearted that so early [in life] he was a fatherless orphan. He carved wood to be his severe parent(s). Morning and night he furnished the three sacrificial animals. An evil-doer insulted [the image]. [Ding] committed a crime through which he could lose his life. The family head [the statue] shed tears for him. [Ding] was exonerated and his [good] name was kept intact. ${ }^{15}$

Although in this version it is not entirely clear whether he made a statue of his father, mother, or both of his parents, the combined words of "severe parent," "fatherless orphan," and "the family head" seem to indicate that it was his father. For Ding Lan his wooden father (or parents) was so important that he risked execution for murdering a neighbor who insulted the statue. His devotion so moved his wooden parent that it shed tears of blood for him.

Eastern Han images of this tale underscore the difficulty of providing reverent care to a statue. Artisans did this by depicting the statue as a mass of wood with merely its top shaped like a human head. ${ }^{16}$ In other words, his wooden "father" only faintly resembled a human. A pictorial stone that was unearthed from Baishazhen in Kaifeng makes this point even clearer: the wooden "statue" is just a mass of wood that has no human features whatsoever. In short, Ding Lan's love for his father is so intense that the wood does not even have a human shape: just associating it with his father is enough for him to treat it with reverent care.

Interestingly, Period of Disunion versions of the Ding Lan tale change the statue's gender. In these later retellings of the story, it is always his mother,

14. See Wu Hung, The Wu Liang Shrine: The Ideology of Early Chinese Pictorial Art (Stanford: Stanford University Press, 1989): 282.

15. Lau, Chen, and Ho, eds, Cao Zhi ji zhuzi suoyin: 106.

16. To see three images of this tale as illustrated at the Wu Liang Shrine, see Wu, The Wu Liang Shrine: 283. For the image of Ding Lan on the pictorial stone from Baishazhen, see Kōshiden chūkai: 435. An image at the Wu Liang Shrine also portrays Ding Lan's father merely as a block of wood. See Liu Xingzhen et al., Han Dynasty Stone Reliefs (Beijing: Foreign Languages Press, 1991): 76-77. 
rather than his father, that is recreated in wood. This might be a reflection that the mother-son relationship was gaining increased significance; hence, to make the story more touching, Ding serves his mother rather than his father. It should be pointed out, though, that most Period of Disunion versions of this tale add in a plot element concerning Ding Lan's wife. In numerous versions she becomes resentful of having to wait hand and foot upon her wooden mother-in-law, so she attacks the image ${ }^{17}$ That is to say, the focus of the tale shifts from the threat of outsiders, in the form of an angry neighbor, to that of internal conflict stemming from the problematic relationship between daughter-in-law and mother-in-law. Hence the gender shift could have been due to a shift in focus on what endangers a family. In Song-Yuan depictions of the tale, although in most cases Ding Lan serves a statue of his mother, in some cases he serves statues of both parents. ${ }^{18}$ This would become the predominant way the story was illustrated during the Ming-Qing (1368-1911) period.

In any case, both the Dong Yong and Ding Lan tales indicate that early medieval readers believed that caring for one's father in a way that underlined his superiority was something that all sons should do; moreover, reverently caring for one's father's needs was a means by which one could express love and concern for him. The tale's images make this point in a concrete manner. Early medieval viewers of the portrayals of these two tales could not but be moved by the tenderness of these sons towards their fathers. One brings his father with him to work every day and constantly checks on his welfare. The other serves a block of wood as though it is a human being, just because he associates it with his father. How could such love for one's father be anything but inspiring?

\section{The reciprocity between father and son}

Another frequent theme in the filial piety stories is one of the reciprocity that is the foundation of the bond between father and son. When their sons are small and helpless, fathers feed and clothe them. When fathers become old and infirm, sons return the favor by feeding and caring for them. In Selfless Offspring, I call this the "care-debt"-the obligation that a son owes his parents for the care they provided for him in infancy and childhood. The necessity of repaying the care-debt appears most starkly in the tale of the filial grandson Yuan Gu. His father detests Yuan Gu's grandfather because he is an economic burden to the family and thus abandons him

17. See Knapp, Selfless Offspring: 191-194.

18. For Song-Yuan illustrations of the Ding Lan tale, see Chen \& Lu, Gansu Song Yuan Huaxiangzhuan: 3, 20, 26, 38, 41, and 63; Zhengzhou gumu bihua jingxuan: 137 and 142; Cui, Pingyang Jinmu zhuandiao: 241, 248, 253, and 257. 
in the mountains. Before returning home, Yuan Gu retrieves the litter with which they transported the grandfather. When his father questions him, Yuan replies,

"When you, father, later become old, I will again use it to abandon you. There then will be no need to make it anew." His stupid and stubborn father regretted the mistake he had made. Once again he went into the mountains, where he welcomed his father and they all returned home. Each morning and evening [Yuan Gu's father] would reverently care for [his father] and he once again became a filial son. Thereupon in the inner quarters, there was no resentment between the superiors and inferiors. ${ }^{19}$

This story reveals that able-bodied men might be tempted to view their elder fathers as nothing more than burdens because they can no longer work. The Funahashi Accounts of Filial Children version of this tale jarringly states that Yuan Gu's parents hated that the grandfather would not die. ${ }^{20}$ Although I doubt that this story indicates that the elderly were frequently abandoned, it does suggest that men sometimes viewed their unproductive and frail fathers as a drain on family resources and an impediment to raising their own family. Through remonstration, Yuan $\mathrm{Gu}$ reminds his father of the reciprocity that is the foundation of the parent-child relationship: men take care of their elderly fathers' needs because they expect the same behavior from their sons. This tale simultaneously indicates that a key aspect of fatherhood was setting an example for one's sons - sons would behave the same way their fathers had. The tale is also noteworthy in that the protagonists are all male; in fact, it shows us the entire patriline of the Yuan family. The purpose of this is to again emphasize the reciprocal nature of relations between father and son.

The resonance this tale had for its audiences cannot be underestimated; it was one of the most frequently illustrated filial piety stories from the Eastern Han all the way through the Yuan dynasty. In the mortuary art of the Song (960-1279), Jin (1115-1234), and the Yuan (1235-1367), under the new name of Yuan Jue or Yuan Jiao, he appears as one of the Ershisi xiao "Twenty-four Filial Exemplars." ${ }^{21}$ Underscoring its enduring popularity, illustrations of this tale were numerous in each period in which filial piety tales were popular; moreover, the illustrated scene remains constant over time: the grandfather sits on a hill or the ground with his knees to his chest, while Yuan Gu, holding the litter, remonstrates with his father. ${ }^{22}$ Despite this narrative's popularity, in his

19. Kōshiden chūkai: 62.

20. Kōshiden chūkai: 62-63.

21. Kuroda, Kōshiden no kenkyū: 265-290.

22. For Eastern Han and Six Dynasties images of the tale, see Kōshiden chūkai: 425-429; Zou, Bei-Wei Xiaozi huaxiang yanjiu: 18, 70, 129-130; and Huang Minglan 黃明蘭, Luoyang Bei-Wei Shisu shikexian huaji 洛陽北魏世俗石刻綫畫集 (Beijing: Renmin 
canonical Ershisi xiao shi "Poems on the Twenty-four Filial Exemplars," Guo Jujing (fl. 1295-1321) decided to omit this tale, possibly because he did not want to show a parent in an unfavorable light. An important aspect of this narrative's images is its emphasis on the grandfather's vulnerability and helplessness - he is usually depicted sitting on the ground or on the litter hunched up like a ball. ${ }^{23}$ Anyone who viewed this image could not but pity the wizened grandfather and revile Yuan Gu's father for treating him so cruelly.

Other tales make the point about reciprocity in a more subtle and less jarring manner. A few stories emphasize the role reversal that takes place within the parent-child relationship. This is best symbolized in the tale of the filial crow. Early medieval Chinese believed that, when older crows became too old to fly, their offspring brought food to them. This filial process by which a young crow fed its parent was called fanbu "to return regurgitation." 24 Two filial piety narratives take this idea of "returning regurgitation" as their theme. The most famous of these concerns the filial son Xing Qu. The Yōmei Archive Accounts of Filial Children tells us that,

There was a Yichun man named Xing Qu who was perfect in his filiality. However, he was poverty-stricken and without a mother. Along with his wife, he only lived together with his father. He would sell his labor for a wage to nurture his father. His father was old in years and could not chew food. Qu would always masticate food for him. Seeing that his father was elderly, night and day Qu was worried and afraid, like he was treading on thin ice. His pure sincerity caused a miraculous response. Heaven thus made his father's white hair turn black once again and made his teeth that had dropped out once again grow. ${ }^{25}$

The noteworthy action within this tale is that, since his father is toothless, Xing Qu masticates his father's food for him. It would seem that he is "returning regurgitation" just like the crow. Also, he is engaging in a form of role reversal in that he is performing an action for his elderly parent, that was done for him when he was a toothless child. It is important here to remember, though, that the parent Xing Qu is doing this for his father. That action implies that his father masticated food for him when he was an infant. Therefore, fathers did indeed play a role in nurturing their children. The same filial action is credited to Zhao

meishu chubanshe, 1987): 6, 77. For Song and Yuan period depictions, see Chen \& Lu, Gansu Song Yuan Huaxiangzhuan: page 9 of the introduction, 8, 14, 29, 34, 37, 45, 48, 54, and 56; Zhengzhou gumu bihua jingxuan: 140; and Cui, Pingyang Jinmu zhuandiao: 244 and 253.

23. See Knapp, Selfless Offspring: 133.

24. For the tale of the filial crow, see Kōshiden chūkai: 269.

25. Kōshiden chūkai: 47. 
Figure \#2: Xing Qu feeds his father with a spoon.

Painting on the Lelang lacquered box. astern Han. $1^{\text {st }}$ or $2^{\text {nd }}$ century AD. North Korea.

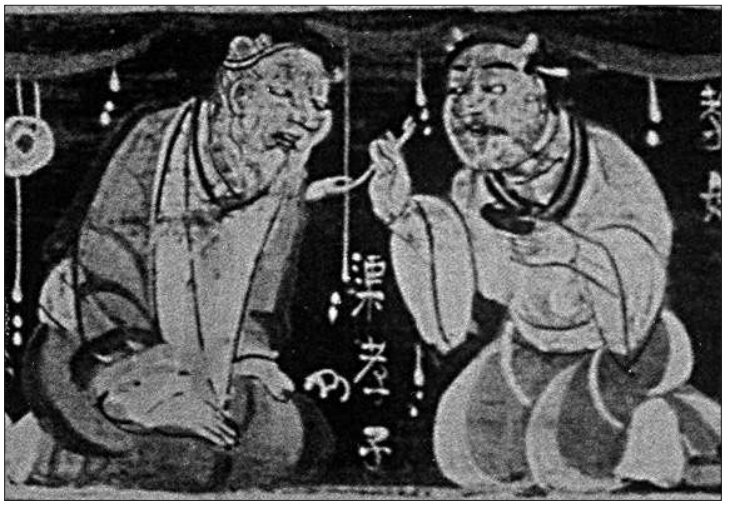

Gou (or Xun); like Xing Qu, he masticates food for his elderly father. That the Xing Qu story resonated well with early medieval Chinese is evident in that this tale was one of the most frequently depicted filial piety tales in Eastern Han art; on the pictorial stones from the Wu family shrine, there are more portrayals of this narrative than any other. The moment in the tale that is emphasized in the images is Xing Qu using chopsticks or a spoon to pass food from his mouth to his father's. In this scene, Xing Qu and his father are portrayed as kneeling and facing each other, while both men incline their heads towards each other to the point where they are very close to one another (see figure \#2). ${ }^{26}$ In an Eastern Han pictorial stone from Dawenkou, which shows Zhao Gou feeding his father, the faces of father and son are almost touching. On the far right of this pictorial stone, there is an image of two birds feeding each other - this image is no doubt meant to invoke the theme of returning regurgitation. ${ }^{27}$ Although the stories of Xing Qu and Zhao Gou continued to be transmitted in writing during the Six Dynasties, no illustrations of these tales postdate the Eastern Han. Obviously, it was during the Eastern Han that these tales had their greatest popularity.

These narratives about returning the feeding and care one received from his father makes Li Shimin's act of sucking his father's nipple, the incident with which this paper began, more intelligible. Early medieval Chinese believed that fathers too played a role in caring for and raising a child. To what extent or how often this happened we do not know; what is clear, though, is that this nurturance

26. See Liu, Han Dynasty Stone Reliefs: 45, 76, 108; Kōshiden chūkai: 415-417.

27. For this image, see Jiang Yingju 蔣英炬, Zhongguo huaxiangshi quanji1: Shandong Han huaxiangshi 中國畫像石全集1：山東漢畫像石 (Jinan \& Zhengzhou: Shandong meishu chubanshe \& Henan meishu chubanshe, 2000): 176-177, and Zou, Bei-Wei Xiaozi huaxiang yanjiu: 65 . 
was not merely symbolic, it actually took material form, which is probably why Eastern Han people found physical displays of returning regurgitation moving. A tale that allows us to understand Li Shimin's act even more is that of the filial servant Li Shan. In premodern China one was supposed to regard servants as lesser members of the family. In turn, servants were supposed to regard their masters as parents; hence, sometimes they called their master "master-father" (zhufu) or "master-mother" (zhumu). Shan was the slave of Li Yuan whose entire family was decimated by an epidemic. The only member of the master's family to survive was an infant boy named Li Xu who was several weeks old. ${ }^{28}$ According to one version of the story, the other servants desired to kill the heir so that they could split the family wealth. Since Shan could not control them, he fled with the infant to a mountain. "He personally fed and nurtured the baby; his breasts on his [the infant's] behalf issued milk. He put him into dry places, while Shan remained in the wet spots." ${ }^{29}$ In the other version of the story, after all the members of the family die, Shan is immediately confronted with the dilemma of how to feed the baby. He borrows milk from neighboring mothers [that is they suckle the baby], but they never give enough to satisfy Xu's hunger. Left at wit's end, Shan cannot control his grief and cries out to Heaven. Soon his breasts swell with milk; Xu is satiated. Upon reaching fifteen years of age, $\mathrm{Li} \mathrm{Xu}$ rewards Shan by giving him the Li family surname. ${ }^{30}$ In both versions, even though Shan is a man, he fulfills the nurturing functions of the mother. Upon reaching the age of fifteen, $\mathrm{Li} \mathrm{Xu}$, the child/master rewards Shan with the bestowal of the Li surname; that is to say, as soon as Li Xu becomes aware that Shan has acted as his parent, $\mathrm{Xu}$ officially incorporates him into the Li family.

This narrative is interesting in the multiple ways it underscores the importance of reciprocity. Shan had strong filial feelings towards his master Li Yuan. One version of the story makes this particularly apparent. After Shan's exemplary behavior became known, the court gave him a series of official posts. On his way to assume new duties, he passed by Li Yuan's grave.

He was not even within a $l i$ of the tomb, when he took off his court robes. He grabbed a hoe and weeded around the tomb. Upon ascending the mound his crying was particularly grief-stricken. He himself started the fire and boiled the [sacrificial] food; he

28. I wonder if the names of the Li family are fictional. Li Yuan literally means "Li the Original." Li Xu literally means "Li the Continuation."

29. Fan Ye 范瞱 (398-445), Hou Han shu 後漢書 (Taipei: Hongye shuju, 1977): 81.2679.

30. See Kōshiden chūkai: 238-239, as well as Yanase Kiyoshi 柳瀬喜代志 and Yahagi Takeishi 矢作武, Chōgyoku shū chūshaku 彫玉集注釈 (Tokyo: Kyuko shoin, 1985): 108-109. 
held the ritual vessels to perform the sacrifice. Weeping he said, "Lord and Missus,

Shan is here." In this manner he exhausted his grief. He only left after several days. ${ }^{31}$

What is remarkable about this tale is that these are the actions usually associated with a filial son; obviously, Shan felt deep affection for his master. It was probably these filial feelings that lead him to protect and nurture Li Yuan's son. Nevertheless, even while he was parenting his master's child, Shan still treated the infant as his master. In short, the tale of Li Shan underscores the unending cycle of reciprocity. Understanding the care-debt that he owes Shan, Li Xu honors Shan by officially making him a part of the family. Shan nurtures and provides for his master's son because of his strong feelings of filial obligation. It is precisely this acute feeling of debt that one owes his parents that motivates caring for children. That Shan could manifest such robust filiality, even though he was merely a slave, emphasizes the depth and profundity of his filial virtue.

Although it might take a miracle to enable a man to suckle his son, certainly the Li Shan tale suggests that fathers too can fulfill the role of nurturer. A late fifth century image of this tale on a lacquered screen makes this point clear: it shows Shan sitting down and cradling a small child to his chest, exactly as one would expect a mother to do. ${ }^{32}$ The tales of Xing Qu and Zhao Gou make the same point, albeit in a slightly more realistic way. Even if a father cannot produce milk, he can certainly obtain and process food to feed it to his children. If early medieval fathers never took part in these feeding activities, how could these images of returning regurgitation be so powerful? Since fathers can nurture like mothers, is it surprising that Li Shimin might emphasize his closeness to his father by sucking his nipple?

\section{Father as Taskmaster}

In early medieval China, fatherhood had its tender moments, especially when children were young and still in need of protection and care. As boys became men, though, the severe aspect of fatherhood came to the fore. To succeed in life, sons had to learn how to obey commands and please their elders. Fathers taught this at home by issuing orders and sternly punishing sons who failed to comply. As indicated in an earlier article, early medieval writers laid increasing emphasis on the unconditional obedience of children. ${ }^{33}$ This is particularly evi-

31. Hou Han shu: 81.2680 .

32. See Kōshiden chūkai: 475.

33. See my "Creeping Absolutism: Parental Authority in Early Medieval Tales of Filial Offspring," in Confucian Cultures of Authority, edited by Roger T. Ames and Peter D. Hershock (Albany: State University of New York Press, 2006): 65-91. 
dent in the filial piety stories, where sons are portrayed as doing whatever their fathers say no matter what the consequences. While serving as a soldier, Hua Bao's (early fifth century) father told him that, upon his return, he would see to it that Bao would be capped (i.e. go through the coming-of-age ceremony) and married. Since his father died before returning, even when he was sixty years of age, Hua Bao still had neither been capped nor married. ${ }^{34}$ Some patriarchs expected that sons would immediately carry out their orders, even if it was a command to commit suicide. Another filial piety tale of this period tells of the heir Chen Xuan. Like many other filial sons, his stepmother slandered him. His father, the Earl of Chen ordered him to commit suicide. Xuan tried to drown himself in the Liao River; however, a big fish carried him on its back and put him on shore. Chen Xuan then told the fish, "I am a criminal; it is only for that reason that I seek death." The fish then left him alone. ${ }^{35}$ Note that even though Xuan had been wrongly accused of something, he views himself as a criminal and deserving of his fate. He knew the truth that he had done no wrong, yet it did not matter; only what his father ordered mattered.

This belief that sons should unconditionally do as their parents directed is even more evident in narratives about pseudo-fathers. A telling story is that of the Sanzhou yishi "The Righteous Men of the Three Regions." Three men each from a different region met under the shade of a tree. They fast became friends and soon discovered that each one was an orphan and without a home. They decided to form a family: the eldest among them became the father while the two others became his sons. To test their sincerity, the "father" ordered his "sons" to erect a home in the middle of the river. The sons immediately set to the task; nevertheless, three years of effort still came to naught - they were unable to fill the river in enough to erect a structure. According to the Funahashi Accounts of Filial Children, the two "sons" said in their despair, "We are unfilial. We have not complied with father's command. The jade in the sea who should it be for? The precious things on the earth should likewise be for whom? Yet, we have not yet even built a small hut, [how] can we be considered people?" ${ }^{6}$ According to this speech, good sons should do anything to benefit their parents, such as seek precious things in faraway places, but they have failed to do even the simplest of tasks - following their father's order to build a cottage. That they engaged in this impossible task for three years underscores their filiality. In short, sons are

34. Ouyang Xun 歐 陽 詢 (557-641), Yiwen leiju 㙯文類聚 (2v. Shanghai: Shanghai guji chubanshe, 1999): 20.371.

35. Yiwen leiju: 96.1672-73; Li Fang 李 昉 (925-996) et al., Taiping yulan 太平 御 覽 (8v. Taipei: Taiwan shangwu yinshuguan, 1986), 416.5b and 935.8b. Taiping yulan $416.5 \mathrm{~b}$ has the most complete account of this tale.

36. See Kōshiden chūkai: 74-75. 
supposed to do whatever their father asks and without question. If pseudo-sons can do this, how much more should real sons! Note that this story was of such importance that it was illustrated at the $\mathrm{Wu}$ Liang shrine. ${ }^{37}$

Another example comes from the Ding Lan tale, which I have already discussed. An interesting feature of this story is that not only does Ding Lan reverently care for his wooden parent, he also asks for its permission when he wants to lend out a hoe. That this was an early element of the story can be seen in the inscription from the Wu Liang shrine, which reads, "When a neighbor wanted to borrow something, only after reporting the matter [to the statue] would he lend it." ${ }^{38}$ Somewhat later versions tell us that, when Ding Lan reported that his neighbor wanted to borrow a hoe or ax, the statue had an unhappy expression; as a result, Ding Lan did not lend him the tool. Since Ding Lan is treating the statue as if it were alive, we have to assume that the author thought that all good sons would do the same thing. That is, since the father was the patriarch who had control of all of the household goods and wealth; consequently, any use of these goods required his approval. That the statue merely had to show its displeasure in its demeanor was enough for Ding Lan to refuse to lend the tool. What is interesting about this story is that the wooden parent had no way to enforce its will; Ding Lan was such a good son that he automatically did the image's bidding. To what degree sons actually behaved this way is unknown; nevertheless, this tale indicates that some men hoped that fathers would have complete control over everything that belonged to their household. Yan Aimin believes that this was indeed the case as a result of the third century law that prohibited fathers and sons from having separate finances. ${ }^{39}$

\section{"Bad" fathers and conniving stepmothers}

Tales that best depict the severity of fathers are those that concern filial sons whose stepmothers mistreated them. Invariably in these anecdotes, the father follows the stepmother's lead and harshly punishes his son. It is important to note, though, that even these "bad" fathers, once they realize their second wives have deceived them, are sympathetic towards their sons. Perhaps the oldest tale of this type concerns Confucius' disciple, Min Ziqian. His stepmother mistreated him, so that the stuffing of his winter clothes was thin. Ziqian's father ordered him to drive the cart, but he dropped the reins several times. After berating him

37. Wu, The Wu Liang Shrine: 299-300.

38. Wu, The Wu Liang Shrine: 282-283.

39. See Yan Aimin 閻愛民, Han-Jin jiazu yanjiu 漢晉家族研究 (Shanghai: Shanghai renmin chubanshe, 2005): 341-342. I believe that this overstates the case and have noted elsewhere that living apart from one's father was still common, particularly in the south. See my "Creeping Absolutism:" 75-79. 


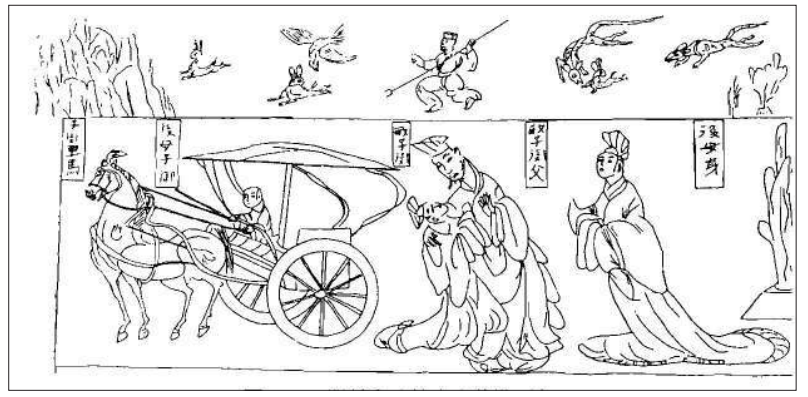

Figure \#3: Min

Ziqian's father discovers that his son's clothing is thin. Line drawing of carving on pictorial stone from Baishazhen in Kaifeng.

his father discovered that Ziqian's hands were cold and his clothing thin, while his stepbrothers' coats were thick and warm. His father then said to the stepmother, "The reason I married you was to take care of my sons, but today you deceive me. Be off and don't tarry!" 40 That is, as soon as Min Ziqian's father realizes that his second wife is mistreating her stepson, he divorces her. As he notes, the point of remarrying was to ensure the welfare of his sons. Although he is at first harsh towards his son, as soon as he knows the truth he thinks only of his son's welfare. This tale was immensely popular to the point that it was continuously depicted artistically from the Eastern Han through modern versions of the "Twenty-four Filial Exemplars". (see figure \#3) (11 $^{4}$

The most dramatic and memorable tales of this type are ones in which the filial son is slandered by his stepmother and his "bad" father attempts to kill him. The most famous of these tales is that of the sage-king Shun. His father Gusou (literally "the blind one") listens to his second wife's slander and twice attempts to murder him. In early medieval versions of the tale, after the second attempt on his life, Shun escapes to Mt. Li. Meanwhile his father has gone blind while his stepmother becomes dumb. While successfully farming at Mt. Li, Shun reverently cares for his father by either slipping coins into the rice he sells to his father or stepmother, or by refusing to accept payment for the rice. In one version, Gusou finally realizes that it is his son who is supporting him when he dreams of a phoenix feeding him rice

40. Lau, Chen, and Ho, Shuoyuan zhuzi suoyin 說 苑逐字索引 (Hong Kong: The Commercial Press, 1992): 187. For Six Dynasties versions of this tale, see Kōshiden chūkai: 177-178.

41. For Eastern Han and Six Dynasties depictions of this story, see Kōshiden chūkai: 454455, Huang, Luoyang Bei-Wei Shisu shikexian huaji: 37. For Song and Yuan period depictions, see Chen \& Lu, Gansu Song Yuan Huaxiangzhuan: 7; Zhengzhou guтu bihua jingxuan: 143 and 145; and Cui, Pingyang Jinmu zhuandiao: 234 and 254. For a twentieth-century illustration of this story, see Arthur Koehn, Filial Devotion in China (Peking: Fu Jen University Press, 1944): 6. 
that it carries in its mouth. ${ }^{42}$ This is obviously the motif of "returning regurgitation." Having finally realized that it is his presumed dead son who is treating him so well, Gusou goes to the market. According to the Funahashi Accounts of Filial Children,

Being led by his second wife, he went to Shun's place to ask him, "Lord, you have repeatedly bestowed kindness upon us, but I am unaware that we have a prior connection?" Shun answered, "I'm your son Shun." At that time, his father cowered on the ground; he shed tears like falling rain. In a loud voice he repented his sins. He felt both amazed and ashamed. Thereupon, Shun used his sleeves to wipe away his father's tears; consequently, his father's eyes immediately regained sight. Shun thereupon saluted and congratulated his father. His father held his son's hands and expressed all of his many regrets and mistakes. Shun filially cared for him as in the past. From that point, [his father] never again changed his heart-mind [away from love for his son]. ${ }^{43}$

Even though Gusou repeatedly tried to kill his son, he realizes his mistake as soon as he understands that his son wants nothing but to provide him with reverent care. Not only does he admit his error, he weeps and repents his sins. In a touching manner, Shun then either licks or wipes his father's eyes, which immediately regain their sight. There can be no doubt this was a tear-jerker for its early medieval audience. The eighth and final scene of the Shun tale on the late fifth-century lacquer sarcophagus in Guyuan, Ningxia, is precisely this one. The inscribed cartouche reads, "The moment where Shun's father is speaking with Shun." "His father's sight was immediately restored." ${ }^{44}$ The image shows Shun raising his hand to touch his father's eyes. In the pre-Han tellings of this tale, Gusou is only shown trying to kill his son; in the early medieval retellings of the tale, father and son become reconciled and both express their love for each other. No wonder this moving narrative was one of the most commonly illustrated filial piety tales during the early medieval period. ${ }^{45}$

A final example of this type of story reveals many father-son tensions and feelings. Bo Qi's father, Yin Jifu, remarried. His stepmother hated Bo Qi. She first secretly put a snake in a pot and asked Bo Qi to take the pot to her young son. She then accused Bo Qi of trying to scare her son to death. When this did not convince her husband that his son from his first marriage was evil, she told her husband that

42. Daoshi 道世 (d. 683), Fayuan zhulin 法苑珠 林 (Qisha Dazangjing ed. Shanghai: Shanghai guji chubanshe, 1991): 49.361.

43. See Kōshiden chūkai: 26.

44. Ningxia Guyuan Bowuguan 寧 夏 固 原 博 物 館, Guyuan Beiweimu qiguan hua 固 原北魏漆棺 畫 (Yinchuan: Ningxia renmin chubanshe, 1988): 12.

45. For Six Dynasties illustrations of this story, see Huang, Luoyang Bei-Wei Shisu shikexian huaji: 8; Guyuan Beiweimu qiguan hua: 11-12; Kōshiden chūkai: 402-409; Zou, Bei-Wei Xiaozi huaxiang yanjiu: 16, 117-120. 
Bo Qi sexually desired her. Her husband responded, "My son's personality is kind and filial, how is it possible that he could act in this way?" Here we see the trust that a father should have for a well-behaved son. To convince him, she had Yin Jifu hide. She then stealthily put bees in her clothing and called Bo Qi over to help get them out. Yin Jifu thereupon saw his son putting his hands into his stepmother's robes. Yin Jifu then said to Bo Qi, "To take your stepmother as a bride like this, can I as your father and superior not be ashamed before Heaven?" ${ }^{46}$ Here the tale alludes to sexual tension that probably sometimes plagued large families in which a father's second wife or concubine might have been the same age or younger than his adult son. At this point, Bo Qi is so ashamed by this accusation that he drowns himself in a river. In many ways, this tale resembles that of the pre-Qin tale of the Jin crown prince Shen Sheng who killed himself rather than disclose to his father that his beloved consort had slandered him.

Because of the early medieval emphasis on the warm feelings between father and son, the tale does not end here. After his son flees, Yin Jifu investigates the matter and discovers that his wife has deceived him. He thereupon sets out after his son on a cart. When he comes upon the river, a ferryman tells him that his son has committed suicide. "When his father heard this, he fainted and was limitlessly racked with grief and pain." He thereupon said,

"My son has been wronged!" At the river, he immediately performed a sacrifice. A flying bird then came to him. His father said, "If you are my son Bo Qi, you should return to my bosom." The bird immediately flew upon his hand and entered into the bosom of his robes, and then emerged from his sleeve. His father then said to him, "You are my Bo Qi. Thus, you should alight onto my cart and follow me home." ${ }^{47}$

Yin Jifu himself discovers the truth of the matter and seeks his son to right the wrong he committed. This is obviously a father who deeply cared about his son. Notice that the bird is supposed to identify itself by returning to his bosom and entering his clothing; the image of Li Shimin suckling Li Yuan's breast immediately comes to mind. Yin Jifu then returns home with Bo Qi the bird perched on his shoulder. When Bo Qi's stepmother sees the bird, she tells Yin Jifu to shoot the inauspicious fowl; he shoots her instead. Bo Qi the bird then pecks out her eyes. ${ }^{48}$ Yin Jifu avenges his son; his son takes his revenge. That this narrative was popular is evident in that illustrations of the tale have been found

46. See Kōshiden chūkai: 189-190.

47. See Kōshiden chūkai: 190.

48. This and the previous paragraph are based on the versions of the story found in the two Kyoto manuscripts. See Kōshiden chūkai: 189-194. 


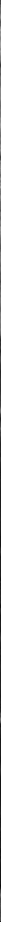

Figure \#4: Bo Qi as the vengeful bird riding on his father's shoulder. Painting on the lacquered Sima Jinlong screen. Datong, Shanxi Province. Northern Wei dynasty, late 5th century.

in northern tombs from the fifth through the eighth centuries (see figure \#4). ${ }^{49}$ The tale also made an impression on the writer and official Yan Zhitui (530-590) who stated, "Jifu was a wise father; Bo Qi was a filial son. A wise father guides his filial son; their harmony gains completion through their heavenly nature. Only afterwards was the second wife able to put distance between them." ${ }^{50}$ Importantly, Yan Zhitui views the harmony that prevails between father and son as coming from their innate nature. It is a natural state of being.

In all three of these stories, those of Min Ziqian, Shun, and Bo Qi, their writers assumed that the relationship between fathers and sons was ordinarily a close one that was marked by the father's concern for his son and the son's devotion to his father. What caused their relationship to falter was the second wife's machinations. In each of these stories it is the stepmother's slander that causes ill will between father and son. This fear of the damage that second wives could do to the father-son relationship is expressed most eloquently by Yan Zhitui

49. Zhao Chao 趙超, “Guanyu Bo Qi de gudai xiaozi tuhua” 關於伯奇的孝子圖畫, Kaogu $y u$ wenwu 考古與文物, $\mathrm{n}^{\circ} 3$ (2004): 68-72. For images of Northern Wei illustrations of this tale, see Kōshiden chūkai: 456-459; Kuroda Akira 黑田彰, Kōshidenzu no kenkyū 孝子伝図の研究 (Tokyo: Kyūko shoin, 2007): 12.

50. Lau, Chen, and Ho, Yanshi jiaxun zhuzi suoyin 顏氏家訓逐字索引 (Hong Kong: Zhongwen daxue chubanshe, 2000): 6. 
who devoted a whole chapter of his Yanshi jiaxun ("The Family Instructions of Mr Yan") to the ways a stepmother might undermine family unity:

North of the Yellow River, people despise the offspring of concubines. They cannot interact with people of position. Therefore, [widowers] must remarry, sometimes three or four times. The mother is [frequently] younger than her [stepson]. The gap in regard to the food, clothing, marriage, and positions that exists between the stepmother's son and that of the stepson is like that between gentlemen and commoners, or the noble and the base. The vulgar take this as normal. After the father dies, it is frequently the case that, in order to set matters straight, lawsuits fill the gates of government halls; slander and insults are made manifest in the streets; sons deride their mothers as concubines; younger brothers castigate their elder brothers as hired laborers; the words and traces of the ancestors are broadcast and spread; and the strengths and weaknesses of one's forbearers are blatantly revealed. ${ }^{51}$

This description of the troubles caused by stepwives and the substandard way they treated their stepchildren indicate that the tales of Min Ziqian, Shun, and Bo Qi responded to a lived reality. It is no wonder that they were so popular. It also indicates that stepmothers were viewed as the wellspring of father-son discord; there was nothing wrong with the father-son relationship itself.

\section{Conclusion}

After reviewing the early medieval filial piety stories, that Li Shimin sucked his father's nipples to suggest his strong feelings of affection for his father no longer seems odd. As I have shown, early medieval men most likely had tender feelings towards their fathers and remembered their early role as care-givers. The illustrations of narratives with the motif of returning regurgitation emphasize the lack of physical distance between father and son. If fathers only cared about their children in the abstract, these tales' emphasis on reverent caring and returning regurgitation would not be so appealing. What makes these motifs so emotionally powerful is that sons were literally returning some of the physical and material care they received as impressionable children. Even more telling are the stories that feature "bad" fathers. These narratives stress that fathers only do horrible things to their sons because of their stepwives' lies. In these tales, fathers naturally love their sons; the relationship only deteriorates because stepmothers drive a wedge between male kin. Fathers might be severe, but they also have tender feelings for their sons.

51. Yanshi jiaxun zhuzi suoyin: 6. For a somewhat different translation, see Yen Chih-t'ui, Family Instructions for the Yen Clan: Yen-shih chia-hsün, translated by Teng Ssu-yü (Leiden: E.J. Brill, 1968): 12-13. 
Another important aspect of these tales about the father-son relationship is the prominence they assume in early medieval pictorial renderings of the tales. Although as already noted, there are fewer tales in which fathers are the recipients of reverent care, stories about fathers often loom large in early medieval pictorial programs. Let us take the late fifth-century Guyuan lacquered sarcophagus as an example. The right side of the sarcophagus has two stories: those of Shun and Guo Ju who buries his infant son to ensure that his mother receives reverent care; that is, one in which the father is the recipient of reverent care and the other the mother. The left side is more heavily damaged, but it appears to have three narratives: Cai Shun who saves his mother's coffin from a fire, Ding Lan who serves his wooden mother, and Bo Qi. Hence, out of the five stories illustrated only two concern fathers. Nevertheless, the tale of Shun is related in eight scenes, which far outnumbers the amount of scenes devoted to the other narratives. ${ }^{52}$ Other Northern Wei artifacts tell the same story in which stories about fathers are prominently displayed..$^{53}$ Thus, despite the fact that there are less stories about sons reverently caring for their fathers, in terms of the pictorial depictions of the tales, the father-son relationship seems to get equal billing with those about the mother-son relationship. Since the pictorially depictions of the tales would have been the most ubiquitous reminders of these stories, the prominence of fathers within the illustrated filial piety stories would have surely influenced their views of filial piety.

Clearly, sons had strong feelings of attachment to both their fathers and mothers. They might have had a more intimate relationship with their mother, but ties with their father were no less important. Fathers physically cared for their young sons, but they soon set up boundaries and expectations for them. Perhaps even more important, through their conduct fathers provided an example for their sons to follow; through their commands, fathers made sure their sons understood their roles. But even as fathers were barking out orders, the authors of Accounts of Filial Children hoped that sons would not forget that, without their father's care and solicitude, they would be nothing.

52. Ningxia Guyuan Bowuguan, Guyuan Beiweimu qiguan hua: 10-14.

53. See Kuroda, Kōshiden no kenkyū: 200-201. 


\section{BiBLIOGRAPHY}

\section{Primary Sources}

Cao Zhi ji zhuzi suoyin 曹植集逐字索引. Edited by Lau, D.C. 劉殿 爵, Chen Fong Ching 陳方正, and Ho Che Wah 何志華. Hong Kong: Zhongwen daxue chubanshe, 2000. Chōgyoku shū chūshaku 彫玉集注釈. Edited by Yanase Kiyoshi 柳瀬喜代志 and Yahagi Takeishi 矢作武. Tokyo: Kyuko shoin, 1985.

Fayuan zhulin 法苑珠林, by Daoshi 道世 (d. 683). Shanghai: Shanghai guji chubanshe, 1991.

Han Feizi zhuzi suoyin 韓非子逐字索引. Edited by Lau, Chen, and Ho. Hong Kong: The Commercial Press, 2000.

Hou Han shu 後漢書, by Fan Ye 范瞱 (398-445). Rpt; Taipei: Hongye shuju, 1977.

Kōshiden chūkai 孝子伝注解. Edited by Yōgaku no Kai 幼學の會. Tokyo: Kyūko shoin, 2003.

Shuoyuan zhuzi suoyin 說苑逐字索引. Edited by Lau, Chen, and Ho. Hong Kong: The Commercial Press, 1992.

Taiping yulan 太平御覽. Edited by Li Fang 李昉 (925-996) et al. 8v. Taipei: Taiwan shangwu yinshuguan, 1986.

Yanshi jiaxun zhuzi suoyin 顏氏家訓逐字索引. Edited by Lau, Chen, and Ho. Hong Kong: Zhongwen daxue chubanshe, 2000.

Yiwen leiju 㙯文類聚. Edited by Ouyang Xun 歐陽詢 (557-641). 2v. Shanghai: Shanghai guji chubanshe, 1999.

[Xinjiao] Zizhi tongjian zhu 新校資治通鑑注. Edited by Yang Jialuo 楊家駱. Rpt; Taipei: Shijie shuju, 1987.

\section{Secondary Sources}

Brown Miranda. "Sons and Mothers in Warring States and Han China, 453 BCE-220 CE.” Nannü no 5.2 (2003): 137-169.

CHEN Lüsheng 陳履生 \& Lu Zhihong 陸志宏. Gansu Song Yuan Huaxiangzhuan 甘 肅的宋元畫像磚. Beijing: Renmin meishu chubanshe, 1996.

Cur Yuanhe 崔元和. Pingyang Jinmu zhuandiao 平陽金墓磚雕. Taiyuan: Shanxi renmin chubanshe, 1999.

Huang Minglan 黃明蘭. Luoyang Bei-Wei Shisu shike xian huaji 洛陽北魏世俗石刻 綫畫集. Beijing: Renmin meishu chubanshe, 1987.

JIANG Yingju 蔣英炬. Zhongguo huaxiangshi quanji 1: Shandong Han huaxiangshi 中國 畫像石全集1: 山東漢畫像石. Jinan \& Zhengzhou: Shandong meishu chubanshe \& Henan meishu chubanshe, 2000. 
KAMIYA Noriko 神矢法子. Haha no tame mofuku: Chugoku kodai shakai ni miru fukenfuken, tsuma=haha no chii ko no gimu 母のための喪服: 中国古代社会に見る 夫権一父権・妻＝母の地位・子の義務. Tokyo: Nihon Tosho Kankokai, 1994.

KnAPP Keith Nathaniel. Selfless Offspring: Filial Children and Social Order in Medieval China. Honolulu: University of Hawaii Press, 2005.

—, «Creeping Absolutism: Parental Authority in Early Medieval Tales of Filial Offspring.» In Confucian Cultures of Authority, edited by Roger T. AMES and Peter D. Hershock: 65-91. Albany: State University of New York Press, 2006.

KURODA Akira 黑田彰. Kōshiden no kenkyū 孝子伝の研究. Kyōtō: Shibunkaku shuppan, 2001.

—, Kōshidenzu no kenkyū 孝子伝図の研究. Tokyo: Kyūko shoin, 2007.

LEE Jen-der, "Wet Nurses in Early Imperial China.” Nannü no 2.1 (2000): 1-39.

Liao W.K. The Complete Works of Han Fei-tzu. 2v. London: Arthur Probsthain, 1959.

Liu Xingzhen \& Yue Fengxia. Han Dynasty Stone Reliefs. Beijing: Foreign Languages Press, 1991.

Ningxia Guyuan Bowuguan 寧夏固原博物 館. Guyuan Beiweimu qiguan hua 固 原 北魏漆棺畫. Yinchuan: Ningxia renmin chubanshe, 1988.

Pearce Scott. "Nurses, Nurslings, and New Shapes of Power in the Mid-Wei Court," Asia Major: Third Series, Part I, 22 (2009): 287-309.

Sнimomi Takao下見隆雄. Jukyô shakai to bosei: bosei no iryoku no kanten de miru Kan Gi Shin Chūgoku joseishi 儒教社會と母性: 母性の威力の観点でみる漢 魏晋中国女性史. Tokyo: Kenbun shuppan, 1994.

一, Kô to bôsei no mekanizumu: Chūgoku joseishi no shiza 孝と母性のメカニズム: 中国女性史の視座. Tokyo: Kyûbun shupan, 1997.

Wu Hung. The Wu Liang Shrine: The Ideology of Early Chinese Pictorial Art. Stanford: Stanford University Press, 1989.

YAN Aimin 閻愛民, Zizhi tongjian 'Shimin gui er shun shangru' de jieshuo-jiantan zhongguo gudai 'ruweng' yisu” 《资治通鉴》'世民跍而吮上乳 “的解説, Zhongguoshi yanjiu 中國史研究, $\mathrm{n}^{\circ} 3$ (2004): 73-78.

一, Han-Jin jiazu yanjiu. 漢晉家族研究. Shanghai: Shanghai renmin chubanshe, 2005.

YEN Chih-t'ui. Family Instructions for the Yen Clan: Yen-shih chia-hsün, translated by Teng Ssu-yü. Leiden: E. J. Brill, 1968.

ZHAo Chao 趙超,Guanyu Bo Qi de gudai xiaozi tuhua” 關於伯奇的孝子圖畫, Kaogu $y u$ wenwu 考古與文物 $\mathrm{n}^{\circ} 3$ (2004): 68-72.

Zhао Yanxia. Father and Son in Confucianism and Christianity: A Comparative Study of Xunzi and Paul. Portland, OR: Sussex Academic Press, 2007.

ZHENG Yaru 鄭雅如. Qinggan yu zhidu: Wei-Jin shidai de muzi guanxi 情感與制度: 魏晋時代的母子關系. Taipei: Guoli Taiwan daxue wenshi congkan, 2001.

Zhengzhou lishi wenhua congshu bianzuan weiyuanhui 鄭州歷史文化叢書編纂委員 會. Zhengzhou gumu bihua jingxuan 鄭州古墓壁畫精選. Hong Kong: Xianggang guoji chubanshe, 1999.

Zou Qingquan 鄒清泉. Bei-Wei xiaozi huaxiang yanjiu: Xiaojing yu Bei-Wei xiaozi huaxiang tuxiang shenfen de zhuanhuan 北魏孝子畵像研究: 孝經與北魏孝子 畫像图像身份的轉换. Beijing: Wenhua yishu chubanshe, 2007. 


\section{GLOSSARY}

Bo Qi 伯奇

Cao Zhi 曹植

chanweng 產翁

Chen Xuan 陳玄

Chu 楚

Dawenkou 大汶口

Dong Yong 董永

Ershisi xiao 二十四孝

Ershisi xiao shi 二十四孝詩

Fanbu 反哺

Gaozu 高祖

gongyang 供飬

Gusou 瞽瞍

Guo Jujing 郭居敬

Han Feizi 韓非子

Hua Bao 華寶

Li Shan 李善

Li Shimin 李世民

$\mathrm{Li} \mathrm{Xu}$ 李續

Li Yuan 李元

Lingzhi pian 靈芝篇

Min Ziqian 閔子騫

ruweng 乳翁

Sanzhou yishi 三州義士

Shen Sheng 申生

Shun 舜

Xiaozi zhuan 孝子傳

Xing Qu 邢渠

Xuanwu 玄武

Yan Aimin 閻愛民

Yanshi jiaxun 顏氏家訓

Yan Zhitui 顏之推

Yichun 宜春

Yin Jifu 尹吉甫

Yuan $\mathrm{Gu}$ 原谷

Yuan Jiao 袁角

Yuan Jue 元覺

Zhao Gou 趙狗

Zhao Xun 趙循

Zhufu 主父

Zhumu 主母 